\title{
Faktor-Faktor yang Mempengaruhi Minat Nasabah dalam Berpartisipasi pada Koperasi Simpan Pinjam di Batam
}

\author{
Golan Hasan
}

Universitas Internasional Batam

golan.hasan@uib.ac.id

\section{Jenny Catherine}

Universitas Internasional Batam

jennycatherine1919@gmail.com

\begin{abstract}
Abstrak Koperasi simpan pinjam memainkan peranan yang penting terhadap perkembangan ekonomi masyarakat di Indonesia. Tujuan utama didirikannya koperasi adalah menjadi motor penggerak ekonomi nasional adalah untuk melindungi kesejahteraan masyarakat dan telah memperluas pendiriannya hingga saat ini. Dengan tujuan membantu anggotanya, koperasi perlu meningkatkan kinerjanya. Namun ada beberapa kendala yang muncul terkait kelemahannya, terutama dalam pengelolaan, keuangan dan partisipasi anggota. Oleh karena itu, penelitian ini bertujuan untuk mengetahui faktor-faktor yang mempengaruhi kinerjanya melalui perencanaan strategis dan partisipasi anggota.
\end{abstract}

Kata Kunci subjective norms, perceived behavioral control, attitude toward behavior, cost advantages dan behavioral intention

\section{PENDAHULUAN}

Koperasi simpan pinjam memainkan peranan yang penting terhadap perkembangan ekonomi masyarakat di Indonesia. Tujuan utama didirikannya koperasi yang menjadi salah satu motor penggerak ekonomi nasional adalah untuk melindungi kesejahteraan masyarakat pedesaan dan telah memperluas pendiriannya hingga saat ini. Dengan tujuan membantu anggotanya, koperasi perlu meningkatkan kinerjanya. Namun ada beberapa kendala yang muncul terkait kelemahannya, terutama dalam pengelolaan, keuangan dan partisipasi anggota. Oleh karena itu, penelitian ini bertujuan untuk mengetahui faktor-faktor yang mempengaruhi kinerjanya melalui perencanaan strategis dan partisipasi anggota.

Ada beberapa faktor yang mempengaruhi kinerja koperasi dan minat masyarakat untuk bergabung menjadi anggota koperasi. Perencanaan strategis, partisipasi anggota, modal manusia, modal struktural dan relasional adalah beberapa faktor yang diidentifikasi. Perencanaan strategis merupakan salah satu faktor yang berkontribusi terhadap kinerja perusahaan. Perencanaan strategis adalah proses menjalankan misi, visi, tujuan, dan tujuan perusahaan. Setiap anggota dan manajemen koperasi harus memahami perencanaan strategis yang mereka miliki dalam organisasi mereka untuk memastikan bahwa bisnis mereka berjalan, bergerak menuju pencapaian tujuan mereka. Sebuah survei yang dilakukan di Amerika melaporkan bahwa koperasi harus memiliki misi, tujuan dan sasaran yang didefinisikan dengan baik. Studi sebelumnya menemukan pengaruh 


\section{JESYA}

JURNAL EKONOMI \& EKONOMI SYARIAH

Jurnal Ekonomi \& Ekonomi Syariah Vol 5 No 1, Januari 2022

E-ISSN : 2599-3410 | P-ISSN : 2614-3259

DOI : https://doi.org/10.36778/jesya.v5i1. 678

signifikan positif dari perencanaan strategis terhadap kinerja koperasi. Hal ini didukung oleh kerangka tentatif yang dikembangkan dalam studi yang dilakukan bahwa dengan memiliki rencana jangka panjang koperasi akan mempengaruhi kinerja koperasi. Pentingnya perencanaan strategis dalam koperasi tidak dapat disangkal karena dalam sebuah penelitian yang dilakukan di Fiji tentang faktor-faktor yang berkontribusi terhadap kinerja koperasi yang berhasil menunjukkan alasan utama bahwa koperasi tidak berhasil di Fiji adalah karena perencanaan yang tidak memadai. Oleh karena itu, penelitian tersebut memasukkan perencanaan strategis sebagai salah satu faktor penting untuk menentukan kinerja koperasi. Selain memiliki perencanaan strategis yang baik, tujuan dan sasaran organisasi dapat tercapai jika ada kontribusi dari anggotanya. Partisipasi diartikan sebagai keterlibatan atau keikutsertaan anggota dalam kegiatan dalam organisasi. Partisipasi anggota dalam kegiatan koperasi terutama dalam tata kelola koperasi sangat penting untuk kelangsungan hidup koperasi dalam jangka panjang.

Partisipasi aktif anggota akan membantu pengurus dalam menjalankan tanggung jawabnya karena pelibatan anggota akan menjaga arah koperasi dalam meningkatkan kinerja koperasi. Kajian yang dilakukan antar koperasi di Malaysia menghasilkan dua elemen utama yang mencerminkan partisipasi anggota yaitu pertama partisipasi dalam proses pengambilan kebijakan melalui kehadiran pada rapat umum tahunan dan kedua adalah perlindungan atas produk dan jasa koperasi yang ditawarkan oleh asosiasi mereka. Penelitian mengidentifikasi partisipasi aktif anggota dalam penyelenggaraan koperasi sebagai faktor kunci yang mempengaruhi keberhasilan kinerja koperasi. Di sisi lain, bukti dari koperasi menunjukkan temuan umum bahwa pengaruh produktivitas dari partisipasi kecil, sekitar 5\% dari total output koperasi (Zabri dan Mohammed 2018).

TPB atau Theory of Planned Behavior dikembangkan dari Theory Reasoned Action (TRA). Teori tersebut menetapkan bahwa kebanyakan perilaku manusia adalah otonom. Perilaku manusia sering dipengaruhi oleh niat perilaku, yang didefinisikan sebagai kemungkinan untuk bertindak dan penentu langsung dari suatu perilaku. Dalam TRA, niat merupakan pertalian dari sikap individu terhadap perilaku dan mereka percaya bahwa orang lain yang penting bagi mereka untuk berpikir bahwa mereka harus bekerja (Nduneseokwu et al., 2017). Banyak perilaku, bagaimanapun tidak selalu otonom. Hal ini mengarah pada salah satu kontribusi TPB yang paling penting yaitu penyertaan pengawasan otonom konsumen pada pengambilan keputusannya. Singkatnya, TPB mendalilkan bahwa niat individu dan perilaku selanjutnya ditentukan oleh tiga faktor: sikap terhadap perilaku, norma subjektif, dan kontrol perilaku yang dirasakan.

\section{LANDASAN TEORI}

Zabri dan Mohammed (2018) meneliti minat warga untuk berpartisipasi dalam model pembiayaan rumah di Malaysia dengan menggunakan prosedur validasi skala yang ketat. Kuesioner diberikan kepada 382 staf akademik dan pendukung, mahasiswa pascasarjana dan sarjana di tiga negara bagian di Malaysia. Data dianalisis menggunakan analisis fakta eksplorasi dan analisis fakta konfirmasi dengan menggunakan SPSS dan AMOS. Hasil penelitian mendukung teori sifat dari perilaku terencana (TPB) dengan tiga konstruk asli dari sikap, norma subjektif, dan kontrol perilaku yang dirasakan dan konstruksi tambahan dari keunggulan biaya yang dirasakan. Penelitian Nduneseokwu et al., (2017) menjelaskan mengenai teori perilaku terencana (TPB) menciptakan platform yang berlaku untuk mengidentifikasi penentu niat daur ulang. Berdasarkan TPB, dikembangkan sebuah kerangka teoritis untuk mempelajari bagaimana sikap, norma subjektif, kontrol perilaku yang dirasakan, dan pengetahuan lingkungan mempengaruhi 
niat untuk berpartisipasi dalam pengumpulan limbah elektronik formal. Menggunakan survei empiris yang dilakukan di Onitsha dengan 384 jawaban kuesioner yang dapat digunakan, untuk mengamati bahwa sikap, sikap subjek, dan pengetahuan lingkungan yang diketahui secara langsung mempengaruhi niat konsumen. Hasil statistik juga menunjukkan bahwa hanya faktor infrastruktur yang memoderasi hubungan antara dua faktor yang mempengaruhi (sikap dan norma subjektif) dan niat. Koefisien negatif yang dihasilkan dari regresi untuk interaksi menunjukkan bahwa pengenalan infrastruktur akan menghasilkan kemampuan yang lebih lemah untuk mempengaruhi sikap dan norma subyektif pada niat.

Penelitian Paftalika1 dan Hananto (2018) menyelidiki bagaimana norma subjektif dan motif dari Uses and Gratifications Theory (UGT) mempengaruhi niat partisipasi berkelanjutan. Selain itu, penelitian ini menguji peran gender sebagai variabel moderasi dalam hubungan. Analisis regresi yang dimoderasi dilakukan pada sampel dari 246 responden yang dipilih dengan teknik purposive sampling. Hasil penelitian menunjukkan bahwa norma subjektif, semua kegunaan, dan motif gratifikasi dalam model (pencarian informasi, penemuan diri, menjaga konektivitas interpersonal, peningkatan sosial, dan nilai hiburan) mempengaruhi keberlanjutan niat partisipasi mahasiswi. Bagi siswa lakilaki, pencarian informasi tidak berpengaruh signifikan terhadap minat partisipasi berkelanjutan. Norma subyektif mempengaruhi siswa laki-laki lebih kuat daripada siswa perempuan.

Penelitian yang dilakukan oleh Shin et al., (2018) bertujuan untuk mengidentifikasi faktor-faktor yang mempengaruhi ketertarikan konsumen untuk memilih dan mengunjungi restoran dengan menu organik di Amerika Serikat. Model penelitian yang dikembangkan theory of planned behavior dan the norm activation model. Dengan total tanggapan kuesioner sebanyak 461, maka hasil penelitian ini menunjukan bahwa sikap, norma subjektif dan persepsi kendali perilaku merupakan faktor penentu ketertarikan konsumen untuk memilih menu organik, yang akhirnya mengarah pada ketertarikan konsumen untuk mengunjungi restoran tersebut.

Penelitian Raab et al., (2017) meneliti variabel sikap, norma subjektif, persepsi kendali perilaku, coercive, mimetic, normative pressure dan behavioral intention. Tujuan penelitan ini yaitu menerapkan institutional theory dan theory of planned behaviour dapat mengidentifikasi motivasi apa yang dapat digunakan oleh manajer restoran dan dengan memeriksa perilaku manajer ketika menghadapi tekanan lingkungan. Hasil penelitian ini mengungkapkan manajer restoran paling dipengaruhi oleh tekanan dari pemasok, pelanggan, sebagian kecil dari karyawan mereka dan oleh harapan masyarakat pada umumnya. Penelitian di masa depan harus menyelidiki sampel manajer restoran nasional.

Penelitian Verma et al., (2017) meneliti hubungan variabel moral reflectiveness, conscientiousness, dan intention to visit green hotels. Tujuan penelitian adalah untuk berupaya memperluas model perilaku sosiologis yaitu Theory of Planned Behavior (TPB) dengan memasukkan dua variabel tambahan yaitu. moral reflectiveness dan conscientiousness untuk mengidentifikasi ketertarikan konsumen muda India untuk mengunjungi hotel ramah lingkungan. Hasil penelitian memberikan dampak positif dari penerapan model TPB dalam mengidentifikasi ketertarikan konsumen muda India untuk mengunjungi hotel ramah lingkungan, karena telah meningkatkan kemampuan prediksi model konseptual yang diusulkan dari 37,5\% menjadi 42,1\%. Studi ini berkontribusi pada teori dan praktik yang ada dengan memberikan wawasan yang bermanfaat tentang moral reflectiveness dan conscientiousness. 


\section{Pengaruh Attitude toward Behavior terhadap Behavioral Intention}

Paftalika1 dan Hananto (2018) mendefenisikan sikap sebagai sejauh mana seseorang memiliki evaluasi atau penilaian yang menguntungkan atau tidak menguntungkan dari perilaku yang bersangkutan. Penelitian sebelumnya telah menetapkan bahwa sikap dapat memprediksi niat perilaku untuk mendatronisasi instrumen jasa keuangan syariah (Rahman et al., 2016). Meskipun banyak penelitian tentang behavioral intention dalam memilih instrument pinjaman yang tepat, menarik untuk dicatat bahwa sebagian besar dilakukan dalam konteks ICB, dan tidak ada yang dilakukan dalam konteks koperasi keuangan. Seperti yang dikemukakan oleh para peneliti mengungkapkan bahwa pinjaman ini berangkat dari bentuk normatifnya. Oleh karena itu, mungkin ada beberapa item sikap pada nilai bisnis dan model koperasi keuangan seperti obligasi biasa yang mungkin tidak ditangkap dalam studi sebelumnya.

\section{Pengaruh Subjective Norms terhadap Behavioral Intention}

Zabri dan Mohammed (2018) mendefenisikan norma subjektif sebagai sebuah tekanan sosial yang dirasakan untuk melakukan atau tidak melakukan suatu perilaku. Dalam studi pemilihan jasa keuangan syariah, tekanan sosial terutama dari anggota keluarga, teman dekat, dan figur yang berpengaruh ditemukan menjadi prediktor yang signifikan dari niat berperilaku (Rahman et al., 2016). Oleh karena itu, jika mereka yang penting bagi mereka mengharapkan mereka untuk berpartisipasi dalam skema yang diizinkan, niat mereka untuk berpartisipasi dalam pinjaman keuangan akan sangat tinggi atau sebaliknya.

\section{Pengaruh Perceived Behavioral Control terhadap Behavioral Intention}

Zabri dan Mohammed (2018) mendefinisikan kontrol perilaku yang dirasakan sebagai sebuah gangguan yang dirasakan atau kesulitan dalam melakukan perilaku danitis yang diasumsikan untuk mencerminkan pengalaman masa lalu serta hambatan dan hambatan yang diantisipasi. Dalam domain studi pemilihan jasa keuangan syariah, persepsi kontrol perilaku ditentukan memiliki pengaruh yang signifikan terhadap niat perilaku (Usman dan Lizam, 2016). Namun, dalam model ini, peserta harus bergabung dengan koperasi keuangan setidaknya selama enam bulan dan menyimpan cukup uang di saham yang akhirnya sama dengan uang muka yang diperlukan untuk membeli rumah mereka. Oleh karena itu, pembeli rumah harus membuat keputusan yang otonom untuk mengatasi kendala tersebut. Jika yang pernah menerima kendala tersebut tinggi, maka niat dan kemampuan untuk berpartisipasi dalam pinjaman akan tinggi.

\section{Pengaruh Cost Advantages terhadap Behavioral Intention}

Cost Advantages merupakan nilai tambah yang didapatkan dari segi biaya yang dapat mendorong nasabah untuk melakukan pinjaman. Meskipun TPB terkenal dengan kesederhanaannya, teori ini, pada prinsipnya, terbuka untuk dimasukkannya prediktor tambahan jika dapat ditunjukkan bahwa mereka menangkap proporsi yang signifikan dari varian dalam niat atau perilaku setelah variabel teori saat ini telah diperhitungkan. Sementara model dalam penelitian ini diusulkan sebagai alternatif yang terjangkau secara finansial dibandingkan dengan model ICB, sangat mungkin bahwa pemilik rumah akan menganggap keunggulan biaya sebagai penentu penting untuk berpartisipasi dalam model. Faktanya, beberapa penelitian menemukan bahwa harga atau persepsi keunggulan biaya keuangan berpengaruh pada nasabah perbankan syariah niat untuk menggunakan perbankan Islam dan layanan keuangan. 
Berdasarkan pembahasan di atas, maka penulis membuat kerangka model penelitian sebagai berikut:

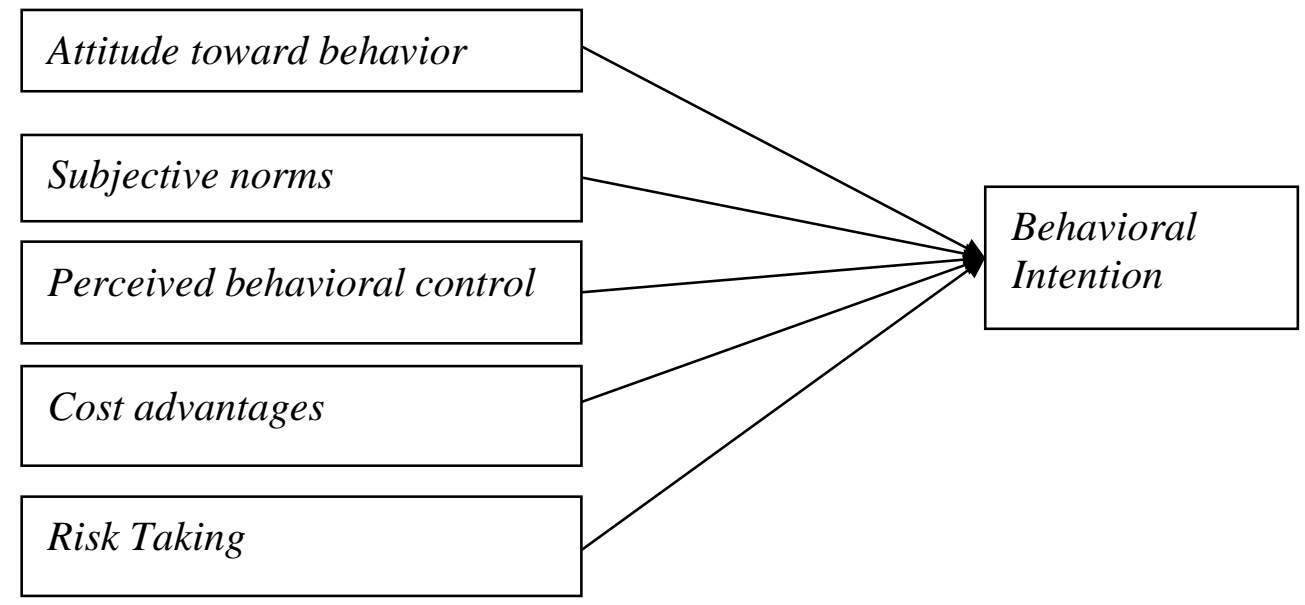

Hipotesis penelitian ini dirumuskan sebagai berikut:

H1: Terdapat pengaruh signifikan antara attitude toward behavior terhadap behavioral intention

H2: Terdapat pengaruh signifikan antara subjective norms terhadap behavioral intention

H3: Terdapat pengaruh signifikan antara perceived behavioral control terhadap behavioral intention

H4: Terdapat pengaruh signifikan antara cost advantages terhadap behavioral intention

H5: Terdapat pengaruh signifikan antara risk taking terhadap behavioral intention

\section{METODOLOGI PENELITIAN}

Nasabah yang meminjam pada koperasi simpan pinjam merupakan obejk dalam penelitian ini. Sehingga populasi dari penelitian ini adalah nasabah dari semua koperasi simpan pinjam di Batam dan yang dijadikan sampel adalah anggota dari 6 koperasi simpan pinjam di Batam yang mempunyai anggota terbanyak. Dengan menggunakan teori Hair et al., (2018), untuk menentukan sampel minimal dengan jumlah 10 kuesioner untuk setiap pertanyaan di kuesioner. Penelitian ini menggunakan 20 pertanyaan sehingga sampel minimum adalah sebanyak 200 orang responden..

\section{HASIL PENELITIAN}

Pengujian ini memberikan bukti bahwa terdapat pengaruh langsung dengan adanya variabel mediasi diantara hubungan variabel yang dikaji. Hasil uji menunjukkan hubungan yang signifikan bila nilai t-statistic melebihi 1,96 dan $\mathrm{P}$ values lebih kecil dari 0,05 . Pengujian direct effect memberikan bukti terdapat pengaruh signifikan dan tidak signifikan antara independen dengan dependen

Tabel 1

Hasil Uji Pengaruh Langsung (Direct Effects) 


\begin{tabular}{|c|c|c|c|}
\hline Variabel $(\mathrm{X} \rightarrow \mathrm{Y})$ & $\begin{array}{c}\mathrm{T}- \\
\text { Statistics }\end{array}$ & $\begin{array}{c}\mathrm{P} \\
\text { values }\end{array}$ & Kesimpulan \\
\hline Attitude towards Behavior -> & & & \\
\hline Behavior Intention & 0.980 & 0.327 & $\mathrm{H}_{1}$ Tidak Signifikan \\
\hline Subjective Norms -> Behavior & & & \\
\hline Intention & 0.327 & 0.744 & $\mathrm{H}_{2}$ Tidak Signifikan \\
\hline Perceived Behavioral Control -> & & & \\
\hline Behavior Intention & 1.345 & 0.179 & $\mathrm{H}_{3}$ Tidak Signifikan \\
\hline Cost Advantage -> Behavior & & & \\
\hline Intention & 4.248 & 0.000 & $\mathrm{H}_{4}$ Signifikan \\
\hline Risk Taking -> Behavior Intention & 2.251 & 0.025 & $\mathrm{H}_{5}$ Signifikan \\
\hline
\end{tabular}

Sumber : Data primer diolah (2021)

\section{KESIMPULAN}

Hipotesis 1 yang menyatakan bahwa terdapat hubungan antara Attitude towards Behavior terhadap Behavior Intention tidak dapat dibuktikan karena nilai t-statistic sebesar 0,980 yang artinya lebih kecil dari 1,96 dan p values lebih besar dari 0,05 sehingga disimpulkan tidak terdapat hubungan antara kedua variabel tersebut. Hal ini menunjukkan perilaku tidak berhubungan dengan minat nasabah untuk meminjam pada koperasi di Batam. Hipotesis 2 yang menyatakan bahwa terdapat hubungan antara Subjective Norms terhadap Behavior Intention tidak dapat dibuktikan karena nilai t-statistic sebesar 0,327 yang artinya lebih kecil dari 1,96 dan p values lebih besar dari 0,05 sehingga disimpulkan tidak terdapat hubungan antara kedua variabel tersebut. Hal ini juga menjelaskan bahwa tidak terdapat hubungan yang signifikan antara norma subjektif dengan minat meinjam pada koperasi simpan pinjam. Hipotesis 3 yang menyatakan bahwa terdapat hubungan antara Perceived Behavioral Control terhadap Behavior Intention tidak dapat dibuktikan karena nilai t-statistic sebesar 1,345 yang artinya lebih kecil dari 1,96 dan p values lebih besar dari 0,05 sehingga disimpulkan tidak terdapat hubungan antara kedua variabel tersebut.

Hipotesis 4 yang menyatakan bahwa terdapat hubungan antara Cost Advantage terhadap Behavior Intention dapat dibuktikan karena nilai t-statistic nya 4,248 yang artinya lebih besar dari 1,96 dan $p$ values lebih besar dari 0,05 sehingga disimpulkan terdapat hubungan antara kedua variabel tersebut. Hal ini menunjukkan bahwa peluang biaya yang dikeluarkan untuk mengurus simpan pinjam berpengaruh signifikan terhadap minat nasabah untuk melakukan peminjaman pada koperasi. Hipotesis 5 yang menyatakan bahwa terdapat hubungan antara Risk Taking terhadap Behavior Intention dapat dibuktikan karena nilai t-statistic nya 2,251 yang artinya lebih besar dari 1,96 dan p values lebih besar dari 0,05 sehingga disimpulkan terdapat hubungan antara kedua variabel tersebut. Hal ini menunjukkan bahwa terdapat hubungan antara pengambilan resiko saat meminjam dengan minat nasabah untuk meminjam pada koperasi simpan pinjam di Batam.

\section{DAFTAR PUSTAKA}

Nduneseokwu, C.K., Qu, Y., \& Appolloni, A. (2017). “Factors Influencing Consumers' Intentions to Participate in a Formal e-Waste Collection System: A Case Study of Onitsha, Nigeria." Sustainability (Switzerland) 9 (6): 1-17. https://doi.org/10.3390/su9060881. 
Paftalika, R.B., \& Hananto, A. (2018). “The Uses and Gratifications Theory, Subjective Norm, and Gender in Influencing Students' Continuance Participation Intention in $\begin{array}{lllll}\text { LinkedIn." Binus } & \text { Business }\end{array}$ https://doi.org/10.21512/bbr.v9i3.4722.

Yeh, T.M, Fan, Y.P., \& Jeng, M.Y. (2019). "The Factors Affecting Older Adults' Intention toward Ongoing Participation in Virtual Reality Leisure Activities." International Journal of Environmental Research and Public Health 16 (3). https://doi.org/10.3390/ijerph16030333.

Zabri, M.Z, \& Mohammed, M.O. (2018). "Examining the Behavioral Intention to Participate in a Cash Waqf-Financial Cooperative-Musharakah Mutanaqisah Home Financing Model." Managerial Finance 44 (6): 809-29. https://doi.org/10.1108/MF-05-2017-0189.

Zhao, H. (2019). "Information Quality or Entities' Interactivity? Understanding the Determinants of Social Network-Based Brand Community Participation." Future Internet 11 (4). https://doi.org/10.3390/fi11040087.

https://inet.detik.com/business/d-4752558/transformasi-koperasi-di-era-digital-sepertiapa 